\title{
水和ジルコニア微粒子の生成速度に及ぼす $\mathrm{ZrOCl}_{2}$ 濃度の影響
}

\author{
松井光二・大貝理治 \\ 東ソー(株)南陽研究所, 746-8501 山口県新南陽市開成町 4560
}

\section{Effects of $\mathrm{ZrOCl}_{2}$ Concentration on the Formation Rate of Hydrous-Zirconia Fine Particles}

Koji MATSUI and Michiharu OHGAI

\author{
Nanyo Research Laboratory, Tosoh Corporation, 4560, Kaisei-cho, Shin-nanyo-shi, Yamaguchi 746-8501
}

\begin{abstract}
In present study, the relationships between the formation ratio and boiling time of hydrous-zirconia fine particles produced by the hydrolysis of aqueous solutions of $\mathrm{ZrOCl}_{2}$ with $0.05-0.4 \mathrm{~mol} \cdot \mathrm{dm}^{-3}$ concentrations were investigated. In particular, emphasis was placed on examining the effect of the $\mathrm{ZrOCl}_{2}$ concentration on the formation rate of hydrous zirconia. The formation time of hydrous-zirconia particles increased with increasing $\mathrm{ZrOCl}_{2}$ concentration. X-ray diffraction measurements revealed that hydrous-zirconia particles synthesized at any $\mathrm{ZrOCl}_{2}$ concentration were similar to those observed for monoclinic crystalline $\mathrm{ZrO}_{2}$. Based on these experimental results, the formation-rate constants $(k)$ of hydrous-zirconia particles produced at 0.05-0.4 mol $\cdot \mathrm{dm}^{-3}$ concentrations were determined experimentally by assuming the formation processes and estimating appropriate values for the acid-dissociation constants. It was clarified that the determined $k$ value decreased with increasing $\mathrm{ZrOCl}_{2}$ concentration. The decrease of the $k$-value can be explained by the decrease of the $k(I)$-term in the ionic strength function contained in $k$.
\end{abstract}

[Received February 2, 1998; Accepted June 19, 1998]

Key-words : Hydrous-zirconia fine particles, Hydrolysis, $\mathrm{ZrOCl}_{2}$ concentration, Formation rate

\section{1. 緒 言}

$\mathrm{Y}_{2} \mathrm{O}_{3}$-Stabilized Tetragonal Zirconia Polycrystals (Y-TZP) は, 高強度・高勒性セラミックスとして知られており, 光ファ イバー接続部品, 精密機械部品, 粉砕機用ビーズ等で商品化さ れている．その原料となる Y-TZP 粉末の合成法として，加水 分解法, 中和共沈法, 及びアルコキシド法などが知られてい る ${ }^{1)}$. 加水分解法の特徵は, $\mathrm{ZrOCl}_{2}$ 及び $\mathrm{YCl}_{3}$ の混合水溶液の 加水分解で得られる水和ジコニア微粒子を乾燥・仮焼するこ とにより，分散性に優れた Y-TZP 粉末が得られることであ

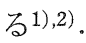

加水分解法で高品質の Y-TZP 粉末を効率的に生産するに は, 水和ジルコニア微粒子の微細構造上生成機構とを明らかに して, Y-TZP 粉末の合成条件を制御する必要がある。水和シ ルコニアの微細構造は, 単斜相に属する 1 次粒子（粒径 $\leqq 10$ $\mathrm{nm})$ が強固に凝集した 2 次粒子であることが知られて抢り3), 著者らは, 種々の $\mathrm{ZrOCl}_{2}$ 水溶液から合成される水和ジコニ アの微細構造をラマン分光法で解析して, 水和ジルコニアの 1 次粒子径は加水分解で生成する $\mathrm{H}^{+}$の濃度に支配されること を報告した ${ }^{4)}$. 水和ジルコニア微粒子の生成機構については, 村瀬らが, $\mathrm{ZrOCl}_{2}$ 水溶液の濃度を変化させて加水分解させる 々, $\mathrm{ZrOCl}_{2}$ 濃度の増加とともに水和ジルコニアの反応終了時 間が増大していくことを報告している5)。むた，加藤らは， $\mathrm{ZrOCl}_{2}$ 及び金属塩化物の混合溶液を加水分解させると, 溶液 中の $\mathrm{Cl}^{-}$量の増加とともに, 水和ジルコニアの生成速度は遅 くなることを報告している6)。このように $\mathrm{ZrOCl}_{2}$ 水溶液から 合成される水和ジルコニアの生成速度は, $\mathrm{ZrOCl}_{2}$ 濃度に影響 されることが現象論的に知られているものの，生成速度に及ほ す $\mathrm{ZrOCl}_{2}$ 濃度の影響を速度論的に解析した例は，これまで報 告されていない.

本研究では, $\mathrm{ZrOCl}_{2}$ 水溶液の濃度を变化させて加水分解反 応を行い, 水和ジルコニア微粒子の生成速度と $\mathrm{ZrOCl}_{2}$ 濃度と の関係を調べた. 得られた結果をもとに水和ジルコニアの生成 速度定数を求めて, 生成速度に及ぼす $\mathrm{ZrOCl}_{2}$ 濃度の影響につ
いて考察した。

\section{2. 実験方法}

2.1 水和ジルコニア微粒子の合成

$\mathrm{ZrOCl}_{2} \cdot 8 \mathrm{H}_{2} \mathrm{O}$ (市販品, 純度 $99.0 \%$ ）を原料に用いて, $\mathrm{ZrOCl}_{2}$ 濃度 $0.05,0.1,0.2$, 及び $0.4 \mathrm{~mol} \cdot \mathrm{dm}^{-3}$ の水溶液を調製 した.これらの出発溶液を還流付きフラスコ中でかくはんしな がら， $100^{\circ} \mathrm{C}$ 温度で煮沸して水和ジルニア微粒子を合成し た (表 1).

\section{2 生成率の測定}

出発溶液のジココルイオン $\left(\mathrm{ZrO}^{2+}\right)$ 濃度は, エチレンジ アミン四酢酸 (市販品) を滴定試薬に用いて, キレート滴定 法7)により分析した。煮沸時に採取した溶液の $\mathrm{ZrO}^{2+}$ 濃度は, 限外沪過（沪過膜; 東ソ一製, UF-3000PS）で得られた沪液 を上記と同様の方法で分析した。水和ジルコニア微粒子の生成 率は, 上記で求めた $\mathrm{ZrO}^{2+}$ 濃度を用いて，(1) 式により算出し た。

$$
\text { 生成率 }(\%)=\frac{\left(\left[\mathrm{ZrO}^{2+}\right]_{\mathrm{s}}-\left[\mathrm{ZrO}^{2+}\right]_{\mathrm{t}}\right)}{\left[\mathrm{ZrO}^{2+}\right]_{\mathrm{s}}} \times 100
$$

ここで, 添字 $\mathrm{s}$ 及び $\mathrm{t} は$, それぞれ出発溶液, 煮沸 $\mathrm{th}$ 後に採 取した溶液の $\mathrm{ZrO}^{2+}$ 濃度を表す。

Table 1. Synthetic Conditions of Hydrous-Zirconia Fine Particles, and the $\mathrm{pH}$ Values before and after the Hydrolysis Reaction

\begin{tabular}{lrll}
\hline $\begin{array}{c}\text { ZrOCl} \\
\left(\mathrm{mol} \cdot \mathrm{dm}^{-3}\right)\end{array}$ & $\begin{array}{c}\text { Boiling time } \\
(\mathrm{h})\end{array}$ & \multicolumn{2}{c}{$\mathrm{pH}\left(30^{\circ} \mathrm{C}\right)$} \\
\hline 0.05 & 75 & 1.6 & 1.3 \\
0.1 & 95 & 1.3 & 0.9 \\
0.2 & 140 & 1.0 & 0.7 \\
0.4 & 165 & 0.7 & 0.4 \\
\hline
\end{tabular}




\section{$2.3 \mathrm{pH}$ 測定}

出発及び反応終了溶液の $\mathrm{pH}$ は, 電気化学計器製 PHL-40を 用いて測定した。これらの溶液は強酸性 $(\mathrm{pH}<2)$ を示すので， それらの溶液を $12 〜 100$ 倍に希橎したあと $30^{\circ} \mathrm{C}$ 温度で $\mathrm{pH}$ 測 定を行い，得られた值を補正して $\mathrm{pH}$ を算出した。

\section{4 粉末 X 線回折の測定}

粉末 $\mathrm{X}$ 線回折（XRD）は，マック・サイエンス製 $\mathrm{MXP}^{3}$ を 用い, $\mathrm{Cu} \mathrm{K} \alpha$ 線を $40 \mathrm{kV}-20 \mathrm{~mA}$ で励起して，スリット幅 $1^{\circ}$ の 条件で測定した。測定試料は，採取された溶液を限外沪過し て，得られた固形物を乾燥させたものを用いた。

\section{3. 結果及び考察}

図 1 は, $\mathrm{ZrOCl}_{2}$ 濃度 $0.05 \sim 0.4 \mathrm{~mol} \cdot \mathrm{dm}^{-3}$ の水溶液の加水分 解により得られた水和ジルコニア微粒子の生成率と惹沸時間と の関係を示す．水和ジルコニアの生成率曲線は，すべての濃度 で $\mathrm{S}$ 字形状を示しており， $\mathrm{ZrOCl}_{2}$ 濃度の増加とともに反応終 了時間が長くなることが分かる。これらの結果は，反応終了時 間の值が異なることを除いては，村瀬らの報告5) とほほ同様の 傾向を示した，反応終了時間の差は，生成率の測定法の違いに よるものと考えられる. 出発溶液及び反応終了溶液の $\mathrm{pH}$ 值を 比較すると（表 1), すべての濃度で反応終了後の $\mathrm{pH}$ が低下 しており，水和ジルコニアの生成とともに $\mathrm{H}^{+}$も生成している ことが分かる. 一般に, 水和ジルコニア微粒子の生成を表す化 学反応式は，(2)式で示されるので4)，これらの $\mathrm{pH}$ 低下は， $\mathrm{ZrOCl}_{2}$ の加水分解で生成する $\mathrm{H}^{+}$量の増加によるものである.

$\mathrm{ZrOCl}_{2}+(n+1) \mathrm{H}_{2} \mathrm{O} \longrightarrow \mathrm{ZrO}_{2} \cdot n \mathrm{H}_{2} \mathrm{O}+2 \mathrm{H}^{+}+2 \mathrm{Cl}^{-}$

図 2 は, $0.05 \sim 0.4 \mathrm{~mol} \cdot \mathrm{dm}^{-3}$ の水溶液から合成された水和 ジルコニア微粒子の XRD パターンを示す。回折線の半值幅は 広いものの，すべての濃度で $28^{\circ}$ 付近に $11 \overline{1} 反$ 射及び $31^{\circ}$ 付近に 111反射に帰属される回折線が現れて抢り，これまでに報告4) されている単斜ジルコニアの結晶構造と同じものである.

以上の結果から, $\mathrm{ZrOCl}_{2}$ 濃度 $0.05 \sim 0.4 \mathrm{~mol} \cdot \mathrm{dm}^{-3}$ の水溶液 を加水分解させると, 単斜相の構造を有する水和ジルコニア微 粒子が生成し, 反応終了時間は $\mathrm{ZrOCl}_{2}$ 濃度の増加とともに長 くなることが分かった。

これらの実験結果をもとに，水和ジルコニア微粒子の生成速 度定数を導出して, 生成速度に及ぼす $\mathrm{ZrOCl}_{2}$ 濃度の影響につ いて考察する. $\mathrm{ZrOCl}_{2} \cdot 8 \mathrm{H}_{2} \mathrm{O}$ は，水溶液中では 4 員環を基本 構造にした 4 核錯体 $\left(\left[\mathrm{Zr}(\mathrm{OH})_{2} \cdot 4 \mathrm{H}_{2} \mathrm{O}\right]_{4}^{8+}\right)$ として存在して おり，この 4 核錯体は (3) 式に示される脱プロトン反応により 配位水から $\mathrm{H}^{+}$を放出することが知られている8)。この水溶液 を加熱すると，（3)式の平衡が右側に変化するので, 脱プロト ン反応の進行とともに結晶性の水和ジルコニア微粒子が形成さ れる ${ }^{8)}$.

$$
\begin{aligned}
& {\left[\mathrm{Zr}(\mathrm{OH})_{2} \cdot 4 \mathrm{H}_{2} \mathrm{O}\right]_{4}^{8+}} \\
& \left.\stackrel{\rightleftarrows}{\rightleftarrows} \mathrm{Zr}(\mathrm{OH})_{2+x} \cdot(4-x) \mathrm{H}_{2} \mathrm{O}\right]_{4}^{(8-4 x)^{+}}+4 \mathrm{H}^{+}
\end{aligned}
$$

Fryer らは, 4 核錯体の存在を仮定して, $\mathrm{ZrOCl}_{2}$ 水溶液の加水 分解反応が，(4)式に示される反応経路で表されることを報告 している9．本結果に抢いても，水和ジルコニアの生成率曲線 が S 字形状を示していることから，水和ジルコニアの生成反 応は，いくつかの素反応段階を経て進行する逐次反応であると 考えられる。

$$
\begin{aligned}
& {\left[\mathrm{Zr}(\mathrm{OH})_{2} \cdot 4 \mathrm{H}_{2} \mathrm{O}_{4}{ }^{8+}\right.} \\
& \quad \longrightarrow\left[\mathrm{Zr}(\mathrm{OH})_{2+x} \cdot(4-x) \mathrm{H}_{2} \mathrm{O}_{4}^{\left({ }^{8-4 x}\right)^{+}}\right. \\
& \quad \longrightarrow\left[\mathrm{Zr}(\mathrm{OH})_{4} \cdot 2 \mathrm{H}_{2} \mathrm{O}\right]_{4} \longrightarrow \mathrm{ZrO}_{2}
\end{aligned}
$$

水和ジルコニア微粒子の生成速度と $\mathrm{ZrOCl}_{2}$ 濃度との関係を

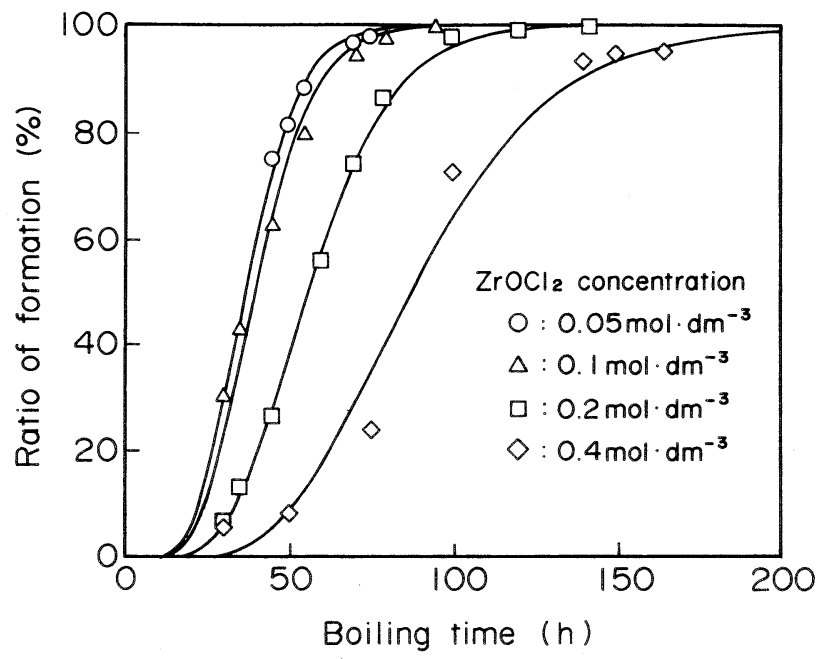

Fig. 1. Relationships between the formation ratio and boiling time for hydrous-zirconia synthesized from various $\mathrm{ZrOCl}_{2}$ solutions. $(\bigcirc),(\triangle),(\square)$ and $(\diamond)$ are the value measured at $\mathrm{ZrOCl}_{2}$ concentrations of $0.05,0.1,0.2$ and $0.4 \mathrm{~mol} \cdot \mathrm{dm}^{-3}$, respectively. The solid line indicate the calculated curve of the formation ratio.

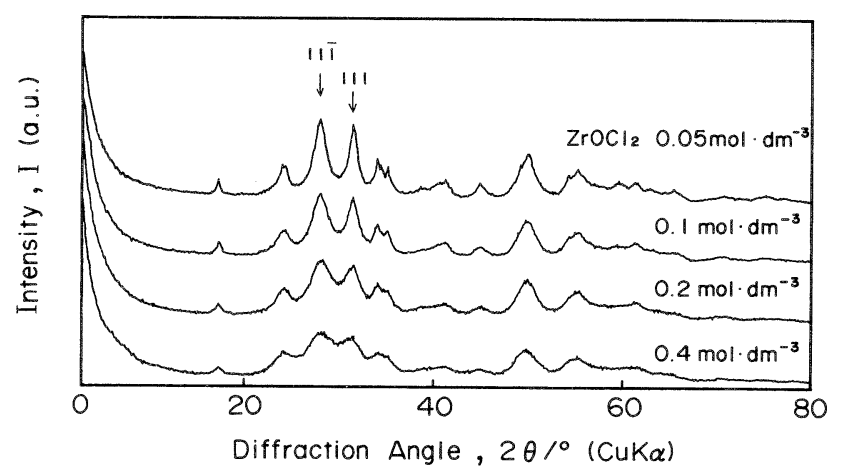

Fig. 2. XRD profiles of hydrous-zirconia fine particles synthesized from various $\mathrm{ZrOCl}_{2}$ solutions.

明らかにするためには，水和ジルコニアの生成反応をいくつか の素反応に分解して，それらの素反応式から生成速度式を誘導 して, 生成速度定数を導出する必要がある。しかしながら, $\mathrm{ZrOCl}_{2}$ の加水分解反応を速度論的に研究した例はこれまでに 報告されておらず，水和ジルコニアの生成速度定数を導出する のに必要な素反応段階については明らかにされていない，そこ で, 本研究では, 上記の(3)及び(4)式から反応過程を類推し て，各段階の素反応は，下記の $(5) \sim(13)$ 式に示される 8 段階 の酸解離平衡々 1 段階の水酸化物から水和物への脱水反応之 で表されると仮定する．以下，下式に示した $\left[\mathrm{Zr}_{4}(\mathrm{OH})_{8} \cdot 16\right.$ $\left.\mathrm{H}_{2} \mathrm{O}\right]^{8+},\left[\mathrm{Zr}_{4}(\mathrm{OH})_{9} \cdot 15 \mathrm{H}_{2} \mathrm{O}\right]^{7+}, \cdots \cdots, \mathrm{ZrO}_{2} \cdot n \mathrm{H}_{2} \mathrm{O}$ の化学種は, 簡略してそれぞれ $Z_{1}{ }^{8+}, Z_{2}{ }^{7+}, \cdots, Z_{10}$ と表記する。

$$
\begin{aligned}
& \underset{\mathrm{Z}_{1}^{8+}}{\left[\mathrm{Zr}_{4}(\mathrm{OH})_{8} \cdot 16 \mathrm{H}_{2} \mathrm{O}\right]^{8+}} \underset{k_{-1}}{\stackrel{k_{1}}{\rightleftarrows}}\left[\underset{\mathrm{Zr}_{4}}{\mathrm{Zr}_{4}}(\mathrm{OH})_{9} \cdot 15 \mathrm{H}_{2} \mathrm{O}\right]^{7+}+\mathrm{H}^{+}
\end{aligned}
$$

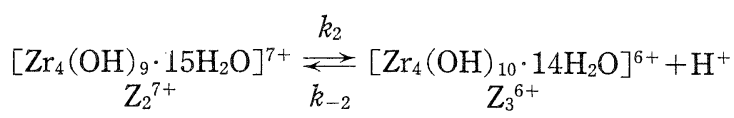


$\left[\mathrm{Zr}_{4}(\mathrm{OH})_{10} \cdot 14 \mathrm{H}_{2} \mathrm{O}\right]^{6+}+\underset{\mathrm{K}_{-3}}{\stackrel{k_{3}}{\rightleftarrows}}\left[\mathrm{Zr}_{4}(\mathrm{OH})_{11} \cdot 13 \mathrm{H}_{2} \mathrm{O}\right]^{5+}+\mathrm{H}^{+}$

$\underset{\mathrm{Z}_{4}^{5+}}{\left.\mathrm{Zr}_{4}(\mathrm{OH})_{11} \cdot 13 \mathrm{H}_{2} \mathrm{O}\right]^{5+}} \underset{k_{-4}}{\stackrel{k_{4}}{\rightleftarrows}}\left[\mathrm{Zr}_{4}(\mathrm{OH})_{12} \cdot 12 \mathrm{H}_{2} \mathrm{O}\right]^{4+}+\mathrm{H}^{+}$

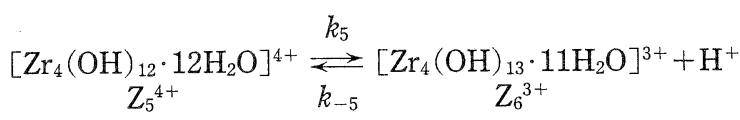

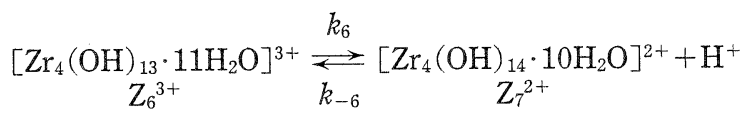

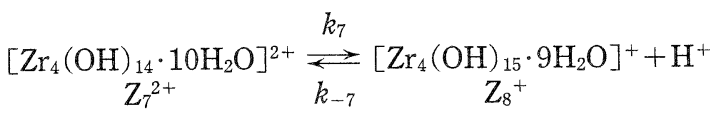

$\underset{\mathrm{Z}_{8}{ }^{+}}{\left[\mathrm{Zr}_{4}(\mathrm{OH})_{15} \cdot 9 \mathrm{H}_{2} \mathrm{O}\right]^{+}} \underset{k_{-8}}{\stackrel{k_{8}}{\rightleftarrows}}\left[\underset{\mathrm{Zr}_{9}}{\left.\stackrel{\mathrm{Zr}_{4}}{(O H}\right)_{16}} \cdot 8 \mathrm{H}_{2} \mathrm{O}\right]+\mathrm{H}^{+}$

$\left.\underset{\mathrm{Z}_{9}}{\left[\mathrm{Zr}_{4}(\mathrm{OH})_{16}\right.} \cdot 8 \mathrm{H}_{2} \mathrm{O}\right] \stackrel{k_{9}}{\longrightarrow} 4 \mathrm{ZrO}_{2} \cdot n \mathrm{H}_{2} \mathrm{O}+(16-4 n) \mathrm{H}_{2} \mathrm{O}$

ここで, $k_{n}(n=1,2, \cdots, 9)$ 及び $k_{-n}(n=1,2, \cdots, 8)$ は, $n$ 段 階の素反応における正及び逆反応の生成速度定数を表す. $n$ 段 階の素反応における熱力学的酸解離定数 (以下, 酸解離定数之 記述する）を $K_{n}(n=1,2, \cdots \cdots, 8)$ とすると， $k_{-n}$ は，

$$
k_{-n}=\frac{k_{n}}{K_{n}}
$$

で表される。

(5)〜 (13) 式及び(14) 式から, 反応時間 $t$ に打ける各化学種 の生成速度式を誘導すると，(15)〜 (25) 式になる。

$$
\begin{aligned}
& \frac{\mathrm{d}\left[\mathrm{Z}_{1}^{8+}\right]}{\mathrm{d} t}=-k_{1}\left[\mathrm{Z}_{1}^{8+}\right]+\frac{k_{1}}{K_{1}}\left[\mathrm{Z}_{2}{ }^{7+}\right]\left[\mathrm{H}^{+}\right] \\
& \frac{\mathrm{d}\left[\mathrm{Z}_{2}{ }^{++}\right]}{\mathrm{d} t}=k_{1}\left[\mathrm{Z}_{1}^{8+}\right]-\frac{k_{1}}{K_{1}}\left[\mathrm{Z}_{2}^{7+}\right]\left[\mathrm{H}^{+}\right]-k_{2}\left[\mathrm{Z}_{2}^{7+}\right] \\
& +\frac{k_{2}}{K_{2}}\left[\mathrm{Z}_{3}{ }^{\mathrm{b}}\right]\left[\mathrm{H}^{+}\right] \\
& \frac{\mathrm{d}\left[\mathrm{Z}_{3}{ }^{6+}\right]}{\mathrm{d} t}=k_{2}\left[\mathrm{Z}_{2}{ }^{7+}\right]-\frac{k_{2}}{K_{2}}\left[\mathrm{Z}_{3}{ }^{6+}\right]\left[\mathrm{H}^{+}\right]-k_{3}\left[\mathrm{Z}_{3}{ }^{6+}\right] \\
& +\frac{k_{3}}{K_{3}}\left[\mathrm{Z}_{4}^{5+}\right]\left[\mathrm{H}^{+}\right] \\
& \frac{\mathrm{d}\left[\mathrm{Z}_{4}{ }^{++}\right]}{\mathrm{d} t}=k_{3}\left[\mathrm{Z}_{3}{ }^{6+}\right]-\frac{k_{3}}{K_{3}}\left[\mathrm{Z}_{4}^{5+}\right]\left[\mathrm{H}^{+}\right]-k_{4}\left[\mathrm{Z}_{4}{ }^{5+}\right] \\
& +\frac{k_{4}}{K_{4}}\left[\mathrm{Z}_{5}^{4+}\right]\left[\mathrm{H}^{+}\right] \\
& \frac{\mathrm{d}\left[\mathrm{Z}_{5}^{4+}\right]}{\mathrm{d} t}=k_{4}\left[\mathrm{Z}_{4}{ }^{5+}\right]-\frac{k_{4}}{K_{4}}\left[\mathrm{Z}_{5}^{4+}\right]\left[\mathrm{H}^{+}\right]-k_{5}\left[\mathrm{Z}_{5}^{4+}\right] \\
& +\frac{k_{5}}{K_{5}}\left[\mathrm{Z}_{6}{ }^{3+}\right]\left[\mathrm{H}^{+}\right]
\end{aligned}
$$

$$
\begin{aligned}
& \frac{\mathrm{d}\left[\mathrm{Z}_{6}^{3+}\right]}{\mathrm{d} t}=k_{5}\left[\mathrm{Z}_{5}^{4+}\right]-\frac{k_{5}}{K_{5}}\left[\mathrm{Z}_{6}{ }^{3+}\right]\left[\mathrm{H}^{+}\right]-k_{6}\left[\mathrm{Z}_{6}{ }^{3+}\right] \\
& +\frac{k_{6}}{K_{6}}\left[\mathrm{Z}_{7}^{2+}\right]\left[\mathrm{H}^{+}\right] \\
& \frac{\mathrm{d}\left[\mathrm{Z}_{7}^{2+}\right]}{\mathrm{d} t}=k_{6}\left[\mathrm{Z}_{6}^{3+}\right]-\frac{k_{6}}{K_{6}}\left[\mathrm{Z}_{7}^{2+}\right]\left[\mathrm{H}^{+}\right]-k_{7}\left[\mathrm{Z}_{7}^{2+}\right] \\
& +\frac{k_{7}}{K_{7}}\left[\mathrm{Z}_{8}{ }^{+}\right]\left[\mathrm{H}^{+}\right] \\
& \frac{\mathrm{d}\left[\mathrm{Z}_{8}{ }^{+}\right]}{\mathrm{d} t}=k_{7}\left[\mathrm{Z}_{7}^{2+}\right]-\frac{k_{7}}{K_{7}}\left[\mathrm{Z}_{8}{ }^{+}\right]\left[\mathrm{H}^{+}\right]-k_{8}\left[\mathrm{Z}_{8}{ }^{+}\right] \\
& +\frac{k_{8}}{K_{8}}\left[\mathrm{Z}_{9}\right]\left[\mathrm{H}^{+}\right] \\
& \frac{\mathrm{d}\left[\mathrm{Z}_{9}\right]}{\mathrm{d} t}=k_{8}\left[\mathrm{Z}_{8}{ }^{+}\right]-\frac{k_{8}}{K_{8}}\left[\mathrm{Z}_{9}\right]\left[\mathrm{H}^{+}\right]-k_{9}\left[\mathrm{Z}_{9}\right] \\
& \frac{\mathrm{d}\left[Z_{10}\right]}{\mathrm{d} t}=4 k_{9}\left[Z_{9}\right] \\
& \frac{\mathrm{d}\left[\mathrm{H}^{+}\right]}{\mathrm{d} t}=k_{1}\left[\mathrm{Z}_{1}{ }^{8+}\right]+k_{2}\left[\mathrm{Z}_{2}{ }^{7+}\right]+k_{3}\left[\mathrm{Z}_{3}{ }^{6+}\right]+k_{4}\left[\mathrm{Z}_{4}^{5+}\right] \\
& +k_{5}\left[\mathrm{Z}_{5}^{4+}\right]+k_{6}\left[\mathrm{Z}_{6}^{3+}\right]+k_{7}\left[\mathrm{Z}_{7}^{2+}\right]+k_{8}\left[\mathrm{Z}_{8}{ }^{+}\right] \\
& -\left(\frac{k_{1}}{K_{1}}\left[\mathrm{Z}_{2}{ }^{7+}\right]\left[\mathrm{H}^{+}\right]+\frac{k_{2}}{K_{2}}\left[\mathrm{Z}_{3}{ }^{6+}\right]\left[\mathrm{H}^{+}\right]\right. \\
& +\frac{k_{3}}{K_{3}}\left[\mathrm{Z}_{4}^{5+}\right]\left[\mathrm{H}^{+}\right]+\frac{k_{4}}{K_{4}}\left[\mathrm{Z}_{5}^{4+}\right]\left[\mathrm{H}^{+}\right] \\
& +\frac{k_{5}}{K_{5}}\left[\mathrm{Z}_{6}^{3+}\right]\left[\mathrm{H}^{+}\right]+\frac{k_{6}}{K_{6}}\left[\mathrm{Z}_{7}^{2+}\right]\left[\mathrm{H}^{+}\right] \\
& \left.+\frac{k_{7}}{K_{7}}\left[\mathrm{Z}_{8}{ }^{+}\right]\left[\mathrm{H}^{+}\right]+\frac{k_{8}}{K_{8}}\left[\mathrm{Z}_{9}\right]\left[\mathrm{H}^{+}\right]\right)
\end{aligned}
$$

\begin{tabular}{|c|c|c|c|}
\hline $\begin{array}{l}\text { Ionic strength } \\
\qquad\left(\mathrm{mol} \cdot \mathrm{dm}^{-3}\right)\end{array}$ & Medium & $\log \mathrm{K}^{*}{ }_{1}$ & $\log \mathrm{K}^{*}{ }_{2}$ \\
\hline 0 & & 1. 13 & 1.13 \\
\hline 1 & $\mathrm{NaClO}_{4}$ & -0.35 & -0.64 \\
\hline 2 & $\mathrm{H}, \mathrm{Li}, \mathrm{ClO}_{4}$ & -1.05 & -1.17 \\
\hline
\end{tabular}

上記の連立 1 階微分方程式を解くためには, 各段階の酸解 離定数について適当な值を見積もる必要がある.4 核錯体の脱 プロトン反応に対する酸解離定数について参考にできる值とし ては，(26)及び(27)式の酸解離平衡に対する, 種々のイオン 強度での酸解離定数 $K_{1}{ }^{*}, K_{2}{ }^{*}\left(25^{\circ} \mathrm{C}\right.$ の值 $)$ が知られている (表 2 ) 10),11)

$$
\begin{array}{llll}
\mathrm{Zr}(\mathrm{OH})_{2}{ }^{2+}+\mathrm{H}_{2} \mathrm{O} \rightleftarrows \mathrm{Zr}(\mathrm{OH})_{3}{ }^{+}+\mathrm{H}^{+} & K_{1}^{*} & \text { (26) } \\
\mathrm{Zr}(\mathrm{OH})_{3}{ }^{+}+\mathrm{H}_{2} \mathrm{O} \rightleftarrows \mathrm{Zr}(\mathrm{OH})_{4}+\mathrm{H}^{+} & \mathrm{K}_{2}{ }^{*} & \text { (27) }
\end{array}
$$

これらの值を比較すると, 図 3 に示すように酸解離定数 $K_{1}{ }^{*}$ 及び $K_{2}{ }^{*}$ は，イオン強度の増加とともにそれぞれ減少してい くことが分かる。ここで, 水溶液のイオン強度 $I$ は, イオン種 $i$ のモル濃度及びイオン価をそれぞれ $c_{\mathrm{i}}, N_{\mathrm{i}}$ として $(28)$ 式で定 義される。

$$
I=\frac{1}{2} \sum c_{\mathrm{i}} N_{\mathrm{i}}^{2}
$$

Table 2. Relationships between the Ionic Strength and the AcidDissociation Constant Reported in References 10) and 11) 


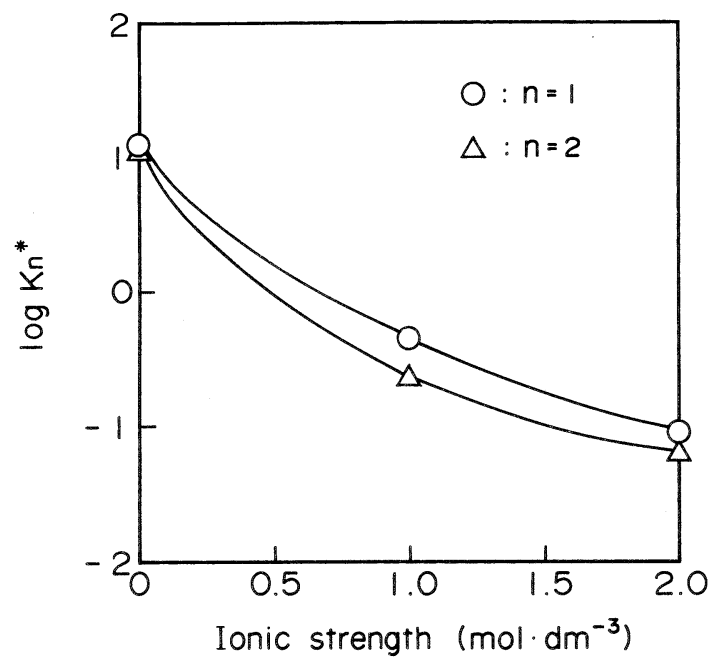

Fig. 3. Dependence of ionic strength on the acid-dissociation constant.

この図 3 に示した関係を用いて, 各濃度での酸解離定数を 求めて, 4 核錯体の各段階の酸解離定数を見積もることにす る. 各出発溶液の $K_{1}{ }^{*}$ 及び $K_{2}{ }^{*}$ の值を求めるために, $\mathrm{ZrOCl}_{2}$ が $\mathrm{Zr}(\mathrm{OH})_{2}{ }^{2+}$ 及び $\mathrm{Cl}^{-}$のイオン種に完全解離しているものと して, 各濃度でのイオン強度を(28)式により算出した。これ らのイオン強度に対応する酸解離定数の值を図 3 から読み取 り，各濃度に抢ける $K_{1}{ }^{*}, K_{2}{ }^{*}$ の值をそれぞれ求めた。得られ た結果を表 3 に示す。 4 核錯体の酸解離平衡は, 個々の水和 $\mathrm{Zr}^{2+}$ イオンから 2 個の $\mathrm{H}^{+}$が放出される 2 段階の解離過程に 分けられるので，前記の(5)〜 (8) 式及び $(9) \sim(12)$ 式はそれぞ れ個々の水和 $\mathrm{Zr}^{2+}$ イオンの 1 段階及び 2 段階の解離過程とし て取り扱うことができる。したがって，(26)式及び(27)式の 酸解離平衡は, それぞれ水和 $\mathrm{Zr}$ イオン 1 原子から 1 個の $\mathrm{H}^{+}$ が放出する反応式なので，4核錯体の酸解離平衡と比較すると, (5)～(8) 式は (26) 式に，(9)～(12)式は (27) 式に対応すると考 えられる。このことから 4 核錯体の酸解離平衡に対する各段 階の酸解離定数を, $K_{1}=K_{2}=K_{3}=K_{4}$ 及び $K_{5}=K_{6}=K_{7}=K_{8}$ に仮定すると， $K_{1}$ 及び $K_{5}$ の值は上記で求めた $K_{1}{ }^{*}$ 及び $K_{2}{ }^{*}$ の值を用いて，それぞれ $K_{1}{ }^{* 1 / 4}, K_{2}{ }^{* 1 / 4}$ 程度に見積もってよい と考えられる。このようにして得られた各濃度での酸解離定数 $K_{1}$ 及び $K_{5}$ の値を表 3 に示した

一方, 定圧下に扔いて, 任意の温度 $T_{1} \rightarrow T_{2}$ に抢ける酸解離 定数 $K_{n}(T)$ の変化は，次式で与えられる.

$$
K_{n}\left(T_{2}\right)=K_{n}\left(T_{1}\right) \cdot \exp \left(\int_{T_{1}}^{T_{2}} \frac{\Delta H^{\circ}(T)}{R T^{2}} \mathrm{~d} T\right)
$$

ここで, $\Delta H^{\circ}(T)$ は, 標準エンタルピー変化であり温度の関 数として表される。また，R及び $T$ は，それぞれ気体定数，

Table 3. Ionic Strengths and Acid-Dissociation Constants of Various $\mathrm{ZrOCl}_{2}$ Solutions

\begin{tabular}{lcrrrr}
\hline $\begin{array}{l}\mathrm{ZrOCl}_{2} \\
\left(\mathrm{~mol} \cdot \mathrm{dm}^{-3}\right)\end{array}$ & $\begin{array}{c}\text { Ionic strength } \\
\left(\mathrm{mol}^{\circ} \cdot \mathrm{dm}^{-3}\right)\end{array}$ & $\operatorname{logK^{*}{}_{1}}$ & $\operatorname{logK^{*}{}_{2}}$ & $\log \mathrm{K}_{1}$ & $\operatorname{logK} 5$ \\
\hline 0.05 & 0.15 & 0.75 & 0.63 & 0.19 & 0.16 \\
0.1 & 0.3 & 0.51 & 0.31 & 0.13 & 0.078 \\
0.2 & 0.6 & 0.11 & -0.18 & 0.028 & -0.045 \\
0.4 & 1.2 & -0.48 & -0.78 & -0.12 & -0.20 \\
\hline
\end{tabular}

Table 4. Acid-Dissociation and Formation-Rate Constants of Various $\mathrm{ZrOCl}_{2}$ Solutions

\begin{tabular}{lccc}
\hline $\begin{array}{l}\mathrm{ZrOCl}_{2} \\
\left(\mathrm{~mol} \cdot \mathrm{dm}^{-3}\right)\end{array}$ & $\mathrm{K}_{1, \mathrm{c}} / \mathrm{K}_{1,0.4} \mathrm{~K}_{5, \mathrm{c}} / \mathrm{K}_{5,0.4}$ & $\mathrm{k}_{1, \mathrm{c}} / \mathrm{k}_{1,0.4}$ \\
\hline 0.05 & 2.0 & 2.3 & 2.3 \\
0.1 & 1.8 & 1.9 & 2.1 \\
0.2 & 1.4 & 1.4 & 1.5 \\
0.4 & 1.0 & 1.0 & 1.0 \\
\hline
\end{tabular}

絶対温度を表す。 2 種の出発溶液の $\mathrm{ZrOCl}_{2}$ 濃度を $C_{1}, C_{2}$ 上表 記して, $T_{1} \rightarrow T_{2}$ までの $K_{n, C 1}(T) / K_{n, C 2}(T)$ 比の変化を,

(29)式放求めると,

$$
\frac{K_{n, C 1}\left(T_{2}\right)}{K_{n, C 2}\left(T_{2}\right)}=\frac{K_{n, C 1}\left(T_{1}\right)}{K_{n, C 2}\left(T_{1}\right)}
$$

になる.この関係式から， 2 種の出発溶液の酸解離定数比は温 度に無関係な值になることが分かる（以下，この酸解離定数比 を $K_{n, C 1} / K_{n, C 2}$ と表記する).

本実験では， $100^{\circ} \mathrm{C}$ 加水分解反応を行っているので，この 反応系に抢ける生成速度定数を導出するためには $100^{\circ} \mathrm{Cでの}$ $K_{1}$ 及び $K_{5}$ の值を必要とする。 しかしながら，水和 $\mathrm{Zr}^{2+}$ イオ ンの酸解離平衡に対する $\Delta H^{\circ}(T)$ にいては知られておらず, (29)式から $100^{\circ} \mathrm{C}$ 值を算出することができないので，各出発

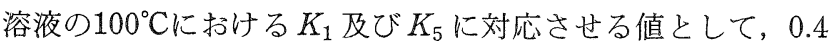
$\mathrm{mol} \cdot \mathrm{dm}^{-3}$ 溶液の酸解離定数に対する比, $K_{1, C} / K_{1,0.4}$ 及び $K_{5, C} / K_{5,0.4}(C=0.05, \cdots, 0.4)$ として表すことにする。 $K_{1, C}$ $K_{1,0.4}$ 及び $K_{5, c} / K_{5,0.4}$ の值は, 表 3 に示した各濃度における $K_{1}$ 及び $K_{5}$ の值を用いて乐れぞれ算出した（表 4 ）。これらの 酸解離定数の比は $25^{\circ} \mathrm{C}$ の值を用いて算出しているが，(30) 式 の関係を考慮すれば, $100^{\circ} \mathrm{C}$ における $K_{1}$ 及び $K_{5}$ に対応させる 值として妥当な酸解離定数比である。

$\mathrm{ZrOCl}_{2}$ 水溶液の各濃度に抢ける各段階の酸解離定数につい て適当な值を見積もることができたので，それらの值を用いて （15）（25) 式の連立 1 階微分方程式を解いて，各段階の生成 速度定数を決定する。図 1 に示した水和ジルコニア微粒子の 生成率と煮沸時間との関係のみを用いて，すべての $k_{n}$ 值を同 時に求められないので, 下記の仮定により決定される $k_{n} に つ$ いて絞り込みを行い， $k_{1}$ の值を実験的に求めることにした。 すなわち, $\mathrm{ZrOCl}_{2}$ 濃度に影響される反応過程は，(5)〜 (12) 式 の酸解離平衡であると考えられるので，これらの解離段階の $k_{n}(n=1,2, \cdots, 8)$ については，(31)式に示すように，同程度 の大きさであり, かつ, 水和ジルコニア微粒子の生成速度を支 配するものと仮定する.

$$
k_{1}=k_{2}=\cdots=k_{8} \ll k_{9}
$$

初期条件として $t=0$ で $Z_{1}^{8+}$ 種のみが存在するとし, $K_{1, c}$ l $K_{1,0.4}$ 及び $K_{5, C} / K_{5,0.4}$ の值を用いて（表 4)，Runge-Kutta 法 ${ }^{12)}$ により連立 1 階微分方程式を解き，水和ジコニアの生 成率曲線に対応する $Z_{10}$ 種の計算曲線が実測值に合うように, $0.05 \sim 0.4 \mathrm{~mol} \cdot \mathrm{dm}^{-3}$ 溶液の生成速度定数を $0.4 \mathrm{~mol} \cdot \mathrm{dm}^{-3}$ 溶液 のものに対する比, $k_{1, c} / k_{1,0.4}(C=0.05, \cdots, 0.4)$ 々して求めた （表 4)．ここで，(13)式の脱水過程については，すべての溶液 で同じ $k_{9}$ 値を用い，その適当な值としては，(31)式の関係か らすべての反応時間で $\left[Z_{10}\right] /\left(\left[Z_{9}\right]+\left[Z_{10}\right]\right) \fallingdotseq 1 の$ 関係をほぼ 


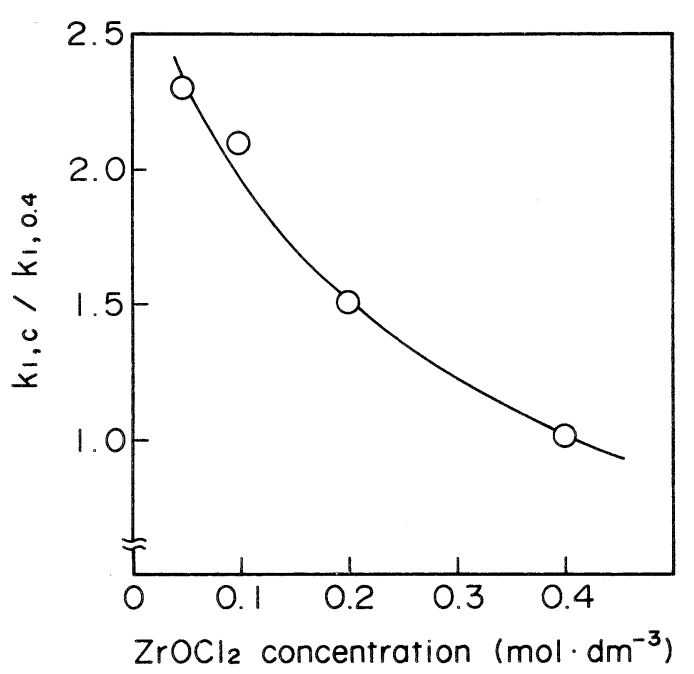

Fig. 4. Dependence of $\mathrm{ZrOCl}_{2}$ concentration on the formationrate constant of hydrous zirconia.

満足する最小の值 $k_{9} / k_{1,0.4}=11$ を用いた. $\mathrm{ZrOCl}_{2}$ 濃度 0.05 $0.4 \mathrm{~mol} \cdot \mathrm{dm}^{-3}$ の水溶液について計算された結果を図 1 の実線 で示すが, 各溶液とも測定值と計算值とがよく一致しているこ とが分かる。図 4 に示されるように，実験的に決定された $k_{1, c} / k_{1,0.4}$ と $\mathrm{ZrOCl}_{2}$ 濃度との関係から, 水和ジルコニア微粒 子の各段階の生成速度定数 $k_{n}(n=1,2, \cdots, 8)$ は, $\mathrm{ZrOCl}_{2}$ 濃度 の増加とともに減少していくことが分かった。

一般に, 電解質溶液に抢ける化学反応の生成速度定数 $k$ は, 次式に示すようにイオン強度 $I$ の関数で表される $k(I)$ 項と $I=0$ に抢ける生成速度定数 $k^{\circ}$ との積で与えられる.

$$
k=k(I) \cdot k^{\circ}
$$

このことから上記で求めた $k_{1, C} / k_{1,0.4}$ は, $k_{1, C}(I) / k_{1,0.4}(I)$ と 同じ值になることが分かる. 出発溶液の $\mathrm{ZrOCl}_{2}$ 濃度が増加す るとイオン強度も増加するので, 濃度増加とともに生成速度定 数 $k$ のの $k(I)$ 項も変化することになる. 本結果では, $\mathrm{ZrOCl}_{2}$ 濃度の増加とともに $k_{1, C}(I) / k_{1,0.4}(I)$ が減少している ので, 濃度增加とともに $k(I)$ 項の值が小さくなって, 生成速 度定数が減少したものと考えられる。

\section{4. 結論}

$\mathrm{ZrOCl}_{2}$ 水溶液の濃度を変化させて加水分解反応を行い, 水 和ジコニア微粒子の生成速度に及ぼす $\mathrm{ZrOCl}_{2}$ 濃度の影響に ついて検討した，得られた結果は，以下のと扬りでる。

(1) $\mathrm{ZrOCl}_{2}$ 水溶液から合成された水和ジルコニア微粒子 は, 単斜相の構造を有する結晶性微粒子であり, $\mathrm{ZrOCl}_{2}$ 濃度 の増加とともに反応終了時間は長くなる傾向を示した。

(2) $\mathrm{ZrOCl}_{2}$ 水溶液の加水分解反応について反応過程を仮定 して, かつ, 酸解離定数の適当な值を見積もることにより水和 シルコニア微粒子の生成速度定数を実験的に導出した. その結 果, $\mathrm{ZrOCl}_{2}$ 濃度の増加とともに生成速度定数は減少していく ことが分かった。

(3) 生成速度定数の $\mathrm{ZrOCl}_{2}$ 濃度依存性は, $\mathrm{ZrOCl}_{2}$ 水溶液 のイオン強度が関与しており, 濃度増加とともにイオン強度 $I$ の関数で表される $k(I)$ 項の值が小さくなって, 生成速度定数 が減少したものと考えられる。

(4) 実験的に求められた生成速度定数と $\mathrm{ZrOCl}_{2}$ 濃度との 関係を用いて, 水和ジコニア微粒子の生成速度式を解くこと により, 出発溶液の $\mathrm{ZrOCl}_{2}$ 濃度の測定から水和ジルコニア微 粒子の反応終了時間を予測することが可能になった。

\section{文献}

1）月舘隆明, 津久間孝二, セラミックス, 17, 816-22 (1982).

2）松井光二, 大貝理治, 嵐 治夫, J. Ceram. Soc. Japan, 103, 593-97 (1995).

3）村瀬嘉夫，加藤悦朗，割協，84, 478-81 (1976)

4) K. Matsui, H. Suzuki, M. Ohgai and H. Arashi, J. Am. Ceram. Soc., 78, 146-52 (1995).

5）村瀬嘉夫, 加藤悦朗, 平野正典, 宰協, 92, 64-70 (1987).

6）加藤悦朗, 江副正信, 近藤正保, 村瀬嘉夫, 的場香磁, 嘿協, 95, 984-90 (1987).

7）上野景平, “キレート滴定法”, 南栄堂 (1979) pp. 40510.

8) A. Clearfiled, Rev. Pure Appl. Chem., 14, 91-108 (1964).

9) J. R. Fryer, J. L. Hutchison and R. Paterson, J. Colloid Interface Sci., 34, 238-48 (1970).

10) L. G. Sillěn, "Stability Constants of Metal-Ion Complexes Sec. I: Inorganic Ligands," The Chemical Society, London (1964) pp. 45-46.

11) L. G. Sillěn, "Stability Constants of Metal-Ion Complexes Supplement No. 1 Part 1: Inorganic Ligands," The Chemical Society, London (1971) p. 18.

12）佐藤次彦, 国宗 真, “物理と化学のための数学 II”, 共立出 版 (1964) pp. 530-40. 